\title{
Biodiesel synthesis by engineered thermo-stable Proteus vulgaris lipase catalysed trans- esterification assisted by Ultrasonication
}

\author{
Shweta Gupta a , Daniel Scott ${ }^{\mathrm{b}}$, C. Ratna Prabha ${ }^{\mathrm{a}}$, and MuthupandianAshokkumar ${ }^{* \mathrm{c}}$ \\ ${ }^{a}$ Department of Biochemistry, Faculty of Science, The Maharaja Sayajirao University of \\ Baroda, Vadodara 390 002, India \\ ${ }^{b}$ Florey Institute of neuroscience and mental health, University of Melbourne, VIC 3010, \\ Australia \\ 'School of Chemistry, University of Melbourne, VIC 3010, Australia
}

\begin{abstract}
Nature has evolved and designed enzymes to perform an exquisite array of tasks, but in the pursuit of biotechnological interests, these enzymes must often be improved, altered, or even completely redesigned. In the present work, production of biodiesel was carried out using Neem oil and methanol catalysed by "engineered” Proteus vulgaris lipase (PVL). Two major issues have been addressed in this study in order to improve the efficiency of biodiesel synthesis by enzyme catalysis. The thermal stability of PVL was increased by introduction of a disulfide bond in G181 and T238 by mutation to cysteines. The transesterification reaction was carried out using sonication under different ultrasonic experimental conditions using a 20 $\mathrm{kHz}$ horn. The results showed that the application of ultrasound decreased the reaction time from 22-24 hrs to 30 minutes with the use of $1 \mathrm{~cm}$ ultrasonic horn, an applied power of $40 \mathrm{~W}$ and methanol to oil molar ratio of 5:1. Temperature raised due to sonication had no effect on engineered PVL (PVL ${ }^{\mathrm{C} 181-238}$ ) activity. A comparative study of wild type (WT-PVL) and engineered PVL ${ }^{\mathrm{C} 181-238}$ for different temperature has been performed and results showed that introduction of a single disulfide in PVL significantly stabilized it, increasing the halfinactivation temperature (IT1/2) from $37^{\circ} \mathrm{C}$ for the WT-PVL to $50^{\circ} \mathrm{C}$ for the PVL ${ }^{\mathrm{C} 181-238}$ engineered one. In biodiesel synthesis also after immobilization on (Polysulfone) PS beads, PVL ${ }^{\mathrm{C} 181-238}$ showed better performance compared to WT- PVL.
\end{abstract}

\section{Keywords}

Lipase: Ultrasonic effect: Thermo-stability: Immobilization: Trans-esterification: Biodiesel *Corresponding Author: 


\section{Introduction}

Enzyme technology is one of the corner stones of industrial biotechnology. Innovative enzyme solutions can potentially improve efficient biomass utilization, and hence significantly contribute to the transition to a bio-based economy by offering environmentally friendly technologies for the production of biofuels, chemicals, and materials from biomass resources. Increased energy demands have turned scientist's interest in search of alternative fuels from renewable sources, as they are biodegradable and lesser toxic. Biodiesel (monoalkyl esters of long-chain fatty acids) is receiving increasing global attention as an attractive replacement for fossil fuel due to its favourable properties like derivation from locally available renewable biological resources, environmental friendly due to reduced emission \& self-subsistent energy source. Although biodiesel is presently being synthesized in many countries, the high cost of production techniques along with the major production from edible oils are the major obstacles for its further development and wide application [1].Methods of biodiesel synthesis from fats \& oils can be grouped into base/acid \& enzymecatalyzed transesterifications [2-4]. The base/acid catalyzed methods are most industrially used but have disadvantage of pre-treatment of oil having high water \& FFA, soap formation, wastewater treatment, difficult separation of biodiesel \& glycerol, catalyst removal compared to enzymatic transesterification [5,6]. Synthesis of biofuel requires efficient methodology with a fewer steps to be economically and environmentally feasible. Lipases have found a wide range of applications, ranging from bioremediation, biosensor development, bioconversion to biofuels and other biotechnologically important value-added products so; the emphasis has therefore been placed on these enzymes and their applications. The lipase catalysed esterification has been considered as friendly and thus "green" for the environment.

Although lipases derived from natural sources can be used in biodiesel production, they typically lack the desirable features that are suitable for industrial scale reactions. Specifically, natural lipases have maximum catalytic activities in the temperature range 30$50^{\circ} \mathrm{C}$. At these temperatures, the transesterification reaction has low reaction rate which makes the process time-consuming and less economically competitive [7]. Increasing the working temperature range of lipases by improving thermal stability, therefore, it is a critical aspect of lipase engineering. The current performance of lipases, however, still falls short of industrial expectations in terms of long-term thermostability. 
In the present work lipase from Proteus vulgaris was explored. Proteus vulgaris belongs to the Proteus/psychrophilic subfamily of I.1 lipases and lack a leader sequence and a disulfide bond present in other family I.1 and I.2 lipases[8]. The lipase from Proteus vulgaris is tolerant to short-chain alcohols ( $\mathrm{MeOH}$ and $\mathrm{EtOH})$ and synthesizes fatty acid methyl esters (biodiesel) even in the presence of high concentration of water [9]. To date, there are no reports of the reengineering of Proteus vulgaris lipase. Thermo-stability is an important property that contributes to the industrial usefulness of an enzyme. The introduction of disulfide bonds is a common strategy to improve enzyme stability that has successfully been applied to other lipases [10]. One of the common drawbacks with the use of enzyme-based processes is the high cost of the enzyme. After immobilization of enzymes, if they can be used repeatedly would bring the cost down and apart from this they have superior thermal and operational stability through a range of $\mathrm{pH}$ values and ionic concentrations and are more resistant to denaturation than their native soluble forms [11-18].

Several studies have used acoustic cavitation and hydrodynamic cavitation to overcome the mass-transfer limitation problem in biodiesel synthesis [19-26]. The chemical and physical effects of ultrasound arise from the acoustic cavitation which produces extreme conditions locally such as high temperature, high pressure, acoustic microstreaming, turbulence, and high shear forces that can help to generate fine emulsions between immiscible fluids to enhance mass transfer and hence the rate of transesterification reaction [27].

The present work was aimed at lipase catalysis in combination with enzyme engineering for the efficient creation of novel and practical biocatalysts (with improved catalytic performance, thermo-stability) for cost effective, high yield enzymatic esterification techniques using immobilized enzyme system for synthesis of biodiesel. The target was to exploit oil from non-feed crops, which is a significant step as the world is facing the energy crisis that disrupts the economic stability \& threatens global security.

\section{Materials and methods}

\subsection{Materials}

Commercially available neem (Azadirachtaindica) oil was used. Lipase genes from Proteus vulgaris are purchased from genescript and a standard fatty acid methyl ester (FAME) mix (chromatographically pure) as a reference were purchased from Sigma-Aldrich. . Primers for cloning and mutagenesis were designed and get from Sterling Biologicals. Escherichia coli 
(DH5Alpa) and vector pIQ- MBP- SacB preserved in laboratory were used for gene cloning, and E. coli BL 21 (DE3) also preserved in laboratory were used for expression. . E. coli $\mathrm{DH} 5 \alpha$ and $\mathrm{BL} 21$ (DE3) were cultured at $37^{\circ} \mathrm{C}$ in Luria-Bertani medium containing 100 $\mu \mathrm{g} / \mathrm{mL}$ Ampicillin for selection. HPLC grade acetonitrile (99.7\%) and hexane (99\%) were purchased from Ajax Finechem. Methanol (99.7\%) was purchased from Scharlau, di-sodium hydrogen orthophosphate (98\%) and sodium dihydrogen orthophosphate (99\%) were purchased from Chem-Supply. Miniprep kits were used from bioline. Polysulfone polymer (Udel P-3500, Solvay Advanced Polymer, India and di-methyl formamide (DMF) (Qualigen, India) were used for beads preparation. Folin reagent (SD fine Chem., India), di-sodium tartarate (SD fine Chem., India), BSA fraction V (Sigma-Aldrich, USA) were used for protein estimation. Acacia powder (SD fine Chem, India) was procured. All solutions were prepared in high purity water extracted from a Millipore system.

\subsection{Methods}

\subsubsection{Disulfide bond introduction}

Pseudomonas aeruginosa and Burkholderia cepacia are homologous lipases (42\% and 38\% ID to PVL, respectively) and they have a single disulfide bond between residues 181 and 238. Due to the structural conservation of this region and the proximity of G181 and T238 in PVL, a disulfide bond was introduced between residues G181 and T238 by mutation to cysteines.

\subsubsection{Cloning of wild type and disulfide introduced lipase gene}

The wild-type and disulfide introduced lipase gene from Proteus vulgaris having BamHI and HindIII sites was cloned into chemically competent DH 5 alpha cells. Lipase gene and the vector pIQ- MBP- SacB were digested with BamHI and HindIII and recovered through agarose gel electrophoresis, and then ligated by T4 DNA ligase having the corresponding sticky ends. The ligated plasmid pIQ- MBP- SacB -lip was transformed into E. coli DH 5 alpha using heat shock method. A single colony of the transformant was selected and transferred into $5 \mathrm{~mL}$ LB broth with $100 \mu \mathrm{g} / \mathrm{mL}$ ampicillin and incubated overnight with vigorous shaking (200 rpm) at $37^{\circ} \mathrm{C}$. The culture was used to extract recombined plasmid through alkaline lysis procedure.

\subsubsection{Expression and purification of WT and mutant PVL ${ }^{\mathrm{C} 181-238}$}

Over-expression of WT-PVL and mutant PVL ${ }^{\mathrm{C} 181-238}$ was carried out in E. coli BL21(DE3) (Agilent). Single transformants were transferred to $2 \mathrm{~L}$ of Luria-Burtani (LB) media containing ampicilin for incubation at $37^{\circ} \mathrm{C}$ and grown to an OD 600 of 0.6. Protein expression was induced by $0.5 \mathrm{mM}$ IPTG at $16^{\circ} \mathrm{C}$ for 16 hours. Cells were harvested by 
centrifugation at $4^{\circ} \mathrm{C}$ for 5 min and purified by Talon IMAC chromatography. The cells were lysed by $0.1 \mathrm{mg} / \mathrm{mL}$ lysozyme, and by sonication using $10 \mathrm{sec}$ on \& $10 \mathrm{sec}$ off for $15 \mathrm{x}$ cycles. Then the supernatant (soluble protein) was harvested by centrifugation at $10,000 \times \mathrm{g}$ at $4^{\circ} \mathrm{C}$ for $20 \mathrm{~min}$. The supernatant (crude enzymes) was removed and directly mixed with 1-mL Talon resin \& incubated for $1 \mathrm{~h}$ at $4^{\circ} \mathrm{C}$ with gentle mixing. Then prepared an empty column PD10 and added the talon/supernatant to the column \& subsequently eluted with an elution buffer (300 mM NaCl, 50 mM sodium phosphate, and $250 \mathrm{mM}$ imidazole, pH 8.0).Wild-type and mutant PVLs were then dialyzed into 20 mMTris- $\mathrm{HCl} \mathrm{pH} 7.5$ containing $100 \mathrm{mM} \mathrm{NaCl}$ and flash frozen as droplets in liquid $\mathrm{N}_{2}$ prior to storage at $-80^{\circ} \mathrm{C}$.

\subsubsection{SDS-PAGE electrophoresis}

The molecular mass of the lipase under denaturing conditions was determined by SDSPAGE. SDS-PAGE was carried out on a 5\% acrylamide stacking gel and 12\% separating gel. Samples were mixed with $2 \times$ loading buffer and heated at $100{ }^{\circ} \mathrm{C}$ for 10 min before electrophoresis. Proteins in the gel were stained with Coomassie brilliant blue R-250.

\subsubsection{Enzyme kinetics and characterization}

Kinetic assays were carried out in 96 well microtiter plates (Grenier Bio-One) with purified protein. For kinetic analysis a stock solution of 86.13 mMpNPP was prepared in 1:1 Acetonitrile:Triton X100. The initial rate of conversion of pNPP to p-nitrophenol was monitored at $405 \mathrm{~nm}$ over the first minute using a plate reader (SpectraMax M5, Molecular Devices). For temperature incubation studies, the residual activity was assayed using 1 mMpNPP in $50 \mathrm{mM}$ phosphate $\mathrm{pH} 7.0$. For temperature inactivation, $60 \mu \mathrm{L}$ of $150 \mathrm{nM}$ enzyme was incubated in $50 \mathrm{mM}$ phosphate $\mathrm{pH} 7.0$ in thin walled PCR using a PCR cycler (MastercyclerProS, Eppendorf). The residual activity remaining as a function of incubation for 1 hour at various temperatures or as a function of time at $50^{\circ} \mathrm{C}$ was determined by hydrolysis of pNPP. Activity was normalized to activity at $25^{\circ} \mathrm{C}$.

\subsubsection{Validation of the formation of disulfide bonds}

To evaluate whether the increasing thermostability of the mutants resulted from the introduction of a disulfide bond, the purified protein was evaluated by the method described by Yang [28].

In brief, the engineered and wild type lipases were treated with $10 \mathrm{mM} \mathrm{DDT}$ at $4^{\circ} \mathrm{C}$ for $12 \mathrm{~h}$; untreated enzyme was used as the control. The residual activities of wild type WT-PVL and 


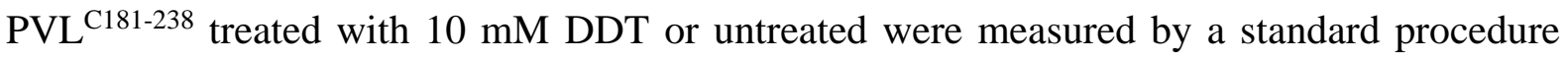
after incubation at $60^{\circ} \mathrm{C}$ for $10 \mathrm{~min}$. The results were calculated as enzyme activity relative to the non-incubated enzymes.

\subsubsection{Immobilization of wild type and engineered PVL and transesterification}

Polymeric (Polysulfone) beads were prepared by wet phase inversion technique as support of lipase immobilization. These lipase loaded beads were used as catalyst for transesterification reaction. Purified B. cepacia, WT-PVL, and mutant lipases (PVL ${ }^{\mathrm{C} 181-238}$ ) were entrapped and adsorbed on hydrophobic lab made Polysulfone (PS) beads. Polysulfone (PS) beads were dried for $4 \mathrm{~h}$ at $50-60^{\circ} \mathrm{C}$ to remove all adsorbed water vapour. PS solution $10 \%(\mathrm{w} / \mathrm{w})$ was prepared in dimethyl formamide (DMF) in heating and stirring condition over 8 h. Then, PS solution was taken in injection syringe (5ml ISI, model No 3236) and poured controlled drop wise into $1 \mathrm{~mL}$ enzyme of $7.5 \mathrm{mg} / \mathrm{mL}$ added in $100 \mathrm{mM}$ sodium phosphate buffer $\mathrm{pH} 7.0$ to complete phase inversion at $25^{\circ} \mathrm{C}$. The aerial path length of the drops was adjusted to $4-5 \mathrm{~cm}$. First immobilization by entrapment was done at the time of beads preparation by wet phase inversion process. Then adsorption was allowed to proceed for $18-24$ hours at $25^{\circ} \mathrm{C}$. Then these prepared lipase loaded globules were treated with 2.5\% glutaraldehyde (crosslinker) to stabilize immobilized lipase from leaching. All two enzymes studied were immobilized by same method. The amount of immobilization was determined by Lowry method [29]. The amount of lipase immobilized was calculated from the difference in concentration of lipase in the initial and final solutions using Bovine Serum Albumin as standard protein

The globules were washed with water and stored in phosphate buffer at $4^{\circ} \mathrm{C}$. The schematic presentation was displayed in our earlier reports [30]. The beads were used for transesterification without further modification. For the synthesis reaction, $0.625 \mathrm{~mL}$ of $50 \%$ methanol (1:1 methanol: $0.1 \mathrm{M}$ phosphate $\mathrm{pH}$ 7.0) was added to the beads followed by 1.5 $\mathrm{mL}$ neem oil. The solution was gently mixed with a vortex and then placed in ultrasonicator. An initial reaction was performed with $0.1 \mathrm{~g}$ beads to establish the transesterification rate for each construct. For the recycling experiment, an appropriate amount of beads $0.20 \mathrm{~g}$ for both the wild-type and engineered PVL were used. For reuse, the beads were washed with $5 \mathrm{~mL}$ buffer followed and then allowed to dry before adding fresh methanol, buffer, and oil.

\subsubsection{Ultrasonication}


Enzymatic transesterification reaction was carried out in a glass cell using a mixture of neem oil, methanol (molar ratio of methanol to oil was 5:1) and PS beads having engineered PVL in aqueous sodium phosphate buffer $(100 \mathrm{mM})$ solution at $\mathrm{pH}$ 7. Ultrasonic horns with tip diameters $1 \mathrm{~cm}$ (BRANSON Digital Sonifier Generator Model 450-D) operating at a frequency of $20 \mathrm{kHz}$ and a maximum rated power output of $400 \mathrm{~W}$ were used to perform transesterification reaction. The power amplitude was adjusted from $10 \%$ to $50 \%$ (40 W - 200 W). The ultrasonic horn was inserted in the reaction mixture to provide sonication. The transesterification reaction without ultrasonic irradiation was also carried out by agitation in a shaker at $150 \mathrm{rpm}$. Most of the reactions were carried out for 15 minutes.

\subsubsection{Analysis of fatty acid methyl esters}

Samples were withdrawn from the reaction mixture at specified time intervals and centrifuged at $6000 \mathrm{rpm}$ to remove the enzyme and to separate biodiesel from glycerol. The biodiesel was then diluted with n-hexane and analysed by gas chromatography (Shimadzhu). $10 \mu \mathrm{L}$ sample was diluted with $1 \mathrm{~mL}$ hexane spiked with $0.5 \mathrm{mg} / \mathrm{mL}$ methyl heptadecanoate (internal standard). The percent conversion will be determined by comparison to a biodiesel sample prepared using a large excess of free lipase. $1 \mu \mathrm{L}$ of the samples at a split ratio of 50:1 were analyzed with flame ionized detector using an HP INNOWax column (Agilent). The carrier gas was helium with a flow rate of $5 \mathrm{~mL} / \mathrm{min}$. The oven temperature was kept at $200^{\circ} \mathrm{C}$ for $3 \mathrm{~min}$ and then raised to 230 at $5^{\circ} \mathrm{C} / \mathrm{min}$ then to 250 at $20^{\circ} \mathrm{C} / \mathrm{min}$ and held at $250^{\circ} \mathrm{C}$ for $9 \mathrm{~min}$. The injector and detector temperatures were kept at 230 and $330^{\circ} \mathrm{C}$ respectively. A reference standard of FAME mix (methyl palmitate, methyl stearate, methyl oleate, methyl linoleate and methyl linolenate) was used for the calibration in order to determine the yield of the product.

\section{Results and Discussion}

\subsection{Introduction of disulphide bond}

Since lipases can be deactivated due to thermal denaturation, thermostability is an important requirement for commercial lipases. In general, increased reaction temperature enhances the solubility of alcohols in oil, which promotes a faster transesterification reaction. Thus, enzymatic catalysts used at high temperatures could increase transesterification yield at shorter reaction times. The introduction of disulfide bonds is a common strategy to improve enzyme thermal stability that has successfully been applied to other lipases [10,31]. Based on 
sequence analysis, we hypothesized that we could stabilize the PVL by the introduction of a disulfide bond. Homologous lipases from Pseudomonas aeruginosa and Burkholderiacepacia (42\% and 38\% ID to PVL, respectively) contain a single disulfide bond between residues 181 and 238 (PVL numbering) that is not conserved in PVL [32,33] but a disulfide bond was introduced between residues G181 and T238 by mutation to cysteines. As we can see in Fig. 1 that wild type p_Vulgaris lipase (WT-PVL) (3) has no disulfide bond. Arrow shows introduction of cysteines at 181 and 238 positions, which we can see in sequence (2) Vulgaris_Cys (PVL ${ }^{\mathrm{C} 181-238}$.) Sequence (1) is showing wild type P. Mirabilis lipase gene.

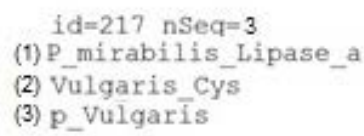

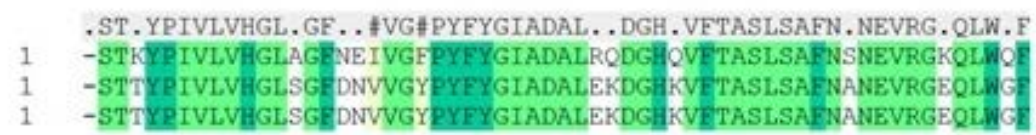

VQ. \#L.ET . . KKVN\#IGHSQGPLACRYVAA. \#\# . \#ASVTSINGVNHGSEIADL \#RRI \#R 60 VQTLLOETOAKKVNFIGHSOGPLACRYVAANYPDSVASVTSINGVNHGSEIADLYRRIME 60 VQKVLKETKAKKVNLIGHSQGPLACR YVAAKHAKNIASVTSINGVNHGSEIADLVRRIVR 60 VQKVLKETKAKKVNLIGHSQGPLACRYVAAKHAKNIASVTSINGVNHGSEIADLVRRIVR

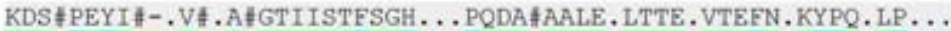
120 KDSI PEYIVEKVLNAFGTIIST FSGH--DPDQDAIAALESLTTEOVTEFNNKYPQALPKTP 120 KDSVPEYIADAVMKAIGTIISTESGHRSNPQDAVAALEALTTENVTEFNKKYPOGI.PAIR 120 KDSVEEY IADAVMKAIGTIISTESGHRSNPQDAVAALEALTTENVTEENKKYPQGLPAIR

GEG, E\#VNGV\#YY, FGSYIQ, LI \#GE, GNLL, PTHAAMRVL . \#FTE. . NDGLVGR, SN 178 GGEGDEIVNGVHYYCFGSYIQGLIAGEKGNLLDPTHAAMRVLNTFETEKQNDGLVGRSSM CGEGKEVVNGVYYYS EGSY IOGLIVGEKGNLLA PTHAAMRVLSAF FTEHENDGLVGRCSI GGEGKEVVNGVYYYS RGSYIQGLIVGEKGNLIAPTHAAMRVLSAFETEHENDGLVGRTSN

RLGKLIKDDYA. DH\#DMVNOVAGLV... E. IVAIYT. HA. ILASK. I 238 RLGKLIKDDYAODH I DMVNOVAGLVGYNEDIVAI YTOHAKYLASKOL 240 RLGKLIKDDYAEDHLDMVNQVAGLVGRGEDIVAI YTNHANFLASKKI 240 RLGKLIKDDYAEDHLDMVNOVAGLVGRGEDIVAI YTNHANFLASKKI

Figure 1: Amino acidsequence alignment of lipase gene (1) Wild type P. Mirabilis, (2) PVL ${ }^{\mathrm{C} 181-238}$; mutant amino acid residues are showed by arrowand (3) Wild type P. vulgaris

\subsection{Cloning, Expression and purification of Wild type and engineered PVL genes:}

Lipase genes were ligated into pIQ-sacB and pIQ-MBP-sacB vectors and then ligations were transformed into DH5Alpha as we can see the ligation in Fig.2. After picking 2 colonies and growing overnight, we miniprepped and nanodropped to determine DNA concentration. The results were for pIQ-sacB WT-PVL $321 \mathrm{ng} / \mathrm{ml} \&$ PVL $^{\mathrm{C} 181-238} 356.21 \mathrm{ng} / \mathrm{ml}$ and for pIQMBP-sacB WT-PVL 332.8 ng/ml \& PVL ${ }^{\mathrm{C} 181-238} 249.6$ ng/ml. 


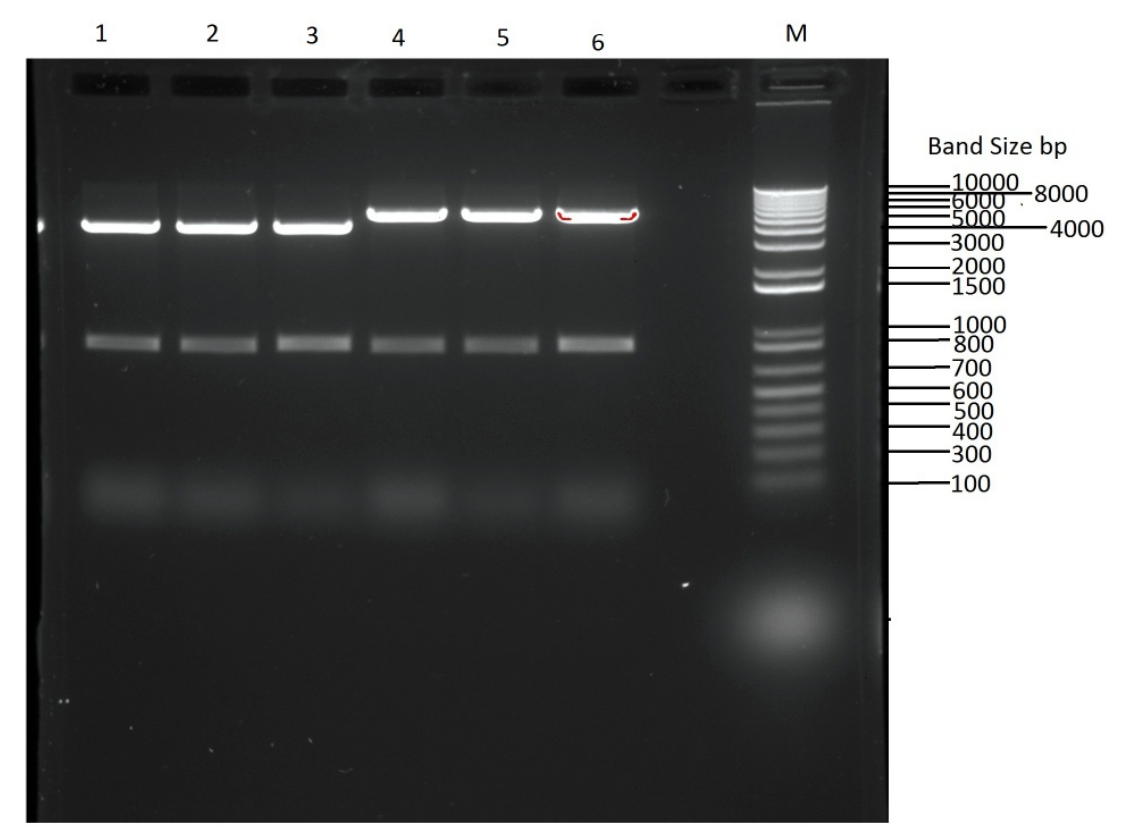

Figure 2: Ligation of lipase gene in pIQ-sacB(well 1,2,3) and pIQ-MBP-sacB vector (well $4,5,6)$

The E. coli BL 21(DE3) transformants pIQ-sacB-WT PVL, pIQ-sacB- PVL ${ }^{\mathrm{C} 181-238}$, pIQMBP-sacB- WT PVL, pIQ-MBP-sacB- PVL ${ }^{\mathrm{C} 181-238}$ were used for inducible expression with $0.5 \mathrm{mM}$ IPTG at $16^{\circ} \mathrm{C}$ for 16 hours. For vector pIQ-MBP-sacB, we found good expression of protein. The total protein of the induced and non-induced transformants was collected and visualized on $12 \%$ SDS-PAGE. As expected, the total protein of the induced E. coli BL 21(DE3) was much more than that of the noninduced cells at the molecular mass $55 \mathrm{kDa}$ (Fig. 3). The crude enzymes were purified by IMAC chromatography using talon resin. Elutions 1,2 and 3 are shown in Fig. 4. 


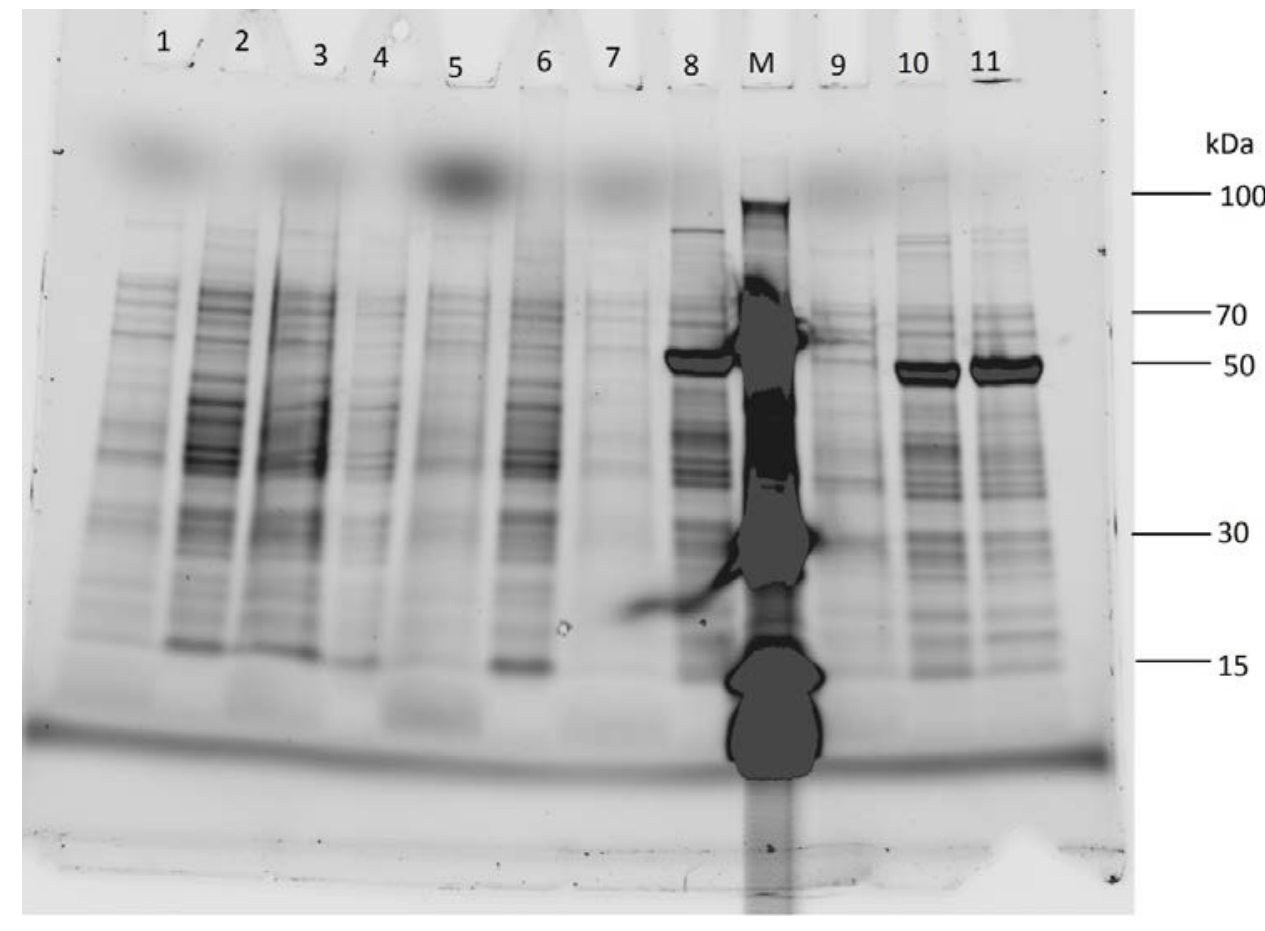

Figure 3: Well 1,2,3,4,5,6 is for pIQ-sacB vector \& well 7,8,9,10,11 for pIQ-MBP-sacB vector. Well 7 pre-inductionWT PVL, well 8 post-inductionWT PVL, well 9 pre-induction PVL ${ }^{\mathrm{C} 181-238}$, well 10,11 post-inductionPVL ${ }^{\mathrm{C} 181-238}$, $\mathrm{M}$ for protein marker.

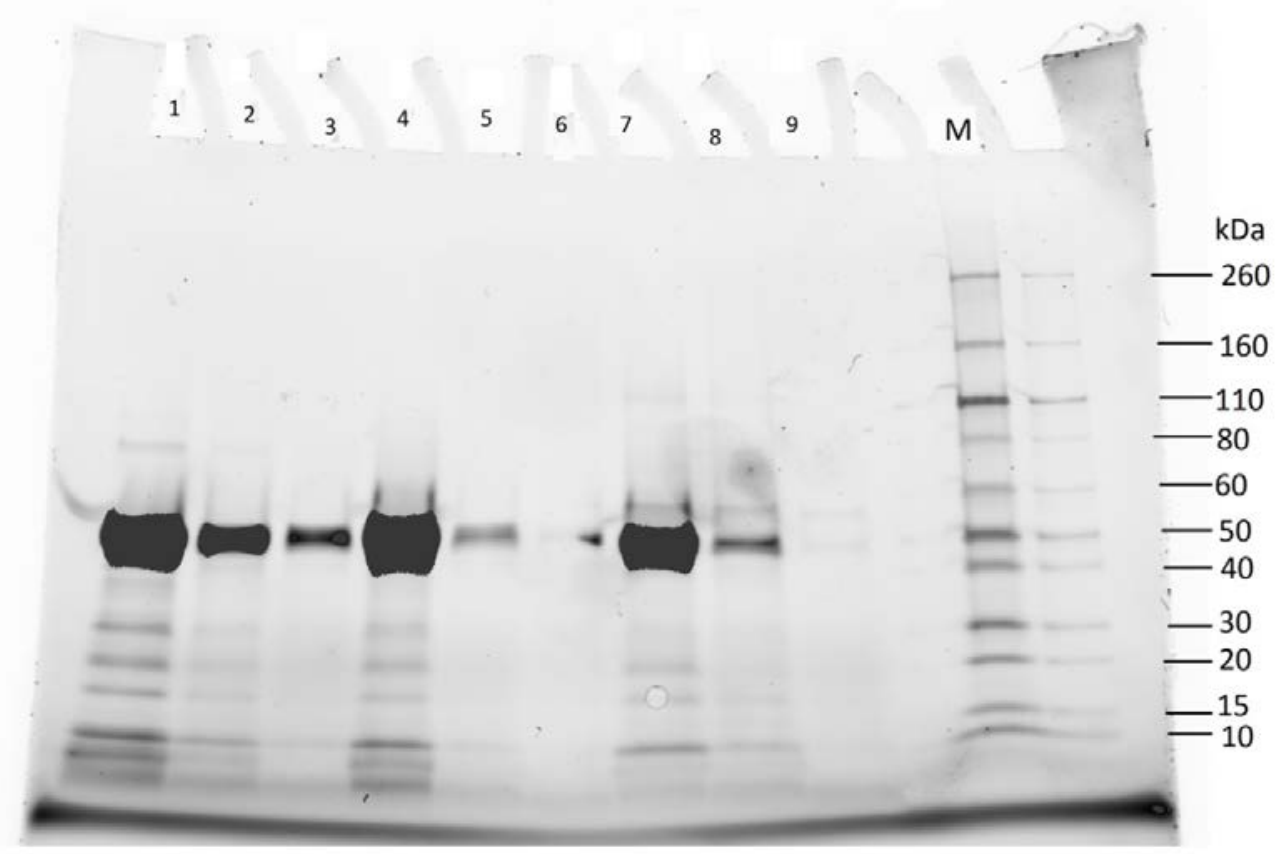

Figure 4: Eluted protein by IMAC (well 1,2,3 is for WT PVL elution 1,2,3 and well 4,5,6 \& 7,8,9 is for $\mathrm{PVL}^{\mathrm{C} 181-238}$ elution 1,2,3 


\subsection{Validation of the disulfide bonds}

The formation of disulfide bonds in PVL ${ }^{\mathrm{C} 181-238}$ was verified by the method described by Yang et al [28]. After treatment with $10 \mathrm{mM}$ DDT at $4^{\circ} \mathrm{C}$ for $12 \mathrm{~h}$, the wild type enzymes were treated by the same procedure as the control. The respective residual activities of $\mathrm{PVL}^{\mathrm{C} 181-238}$ after incubatingat $60^{\circ} \mathrm{C}$ for $10 \mathrm{~min}$ decreased to $29.6 \%$, which is significantly lower than that of the untreated mutants, but DDT-treated WT-PVL retained almost the same residual activity as the untreated enzyme at $60^{\circ} \mathrm{C}$ for $10 \mathrm{~min}$. It indicates that the activity decrease is due to disulfide bond in PVL ${ }^{\mathrm{C} 181-238}$.

\subsection{Characterization of thermostability}

The improvement in thermal stability by introduction of a disulfide bond was examined by monitoring the residual lipase activity after heat treatment. For this purpose the samples were incubated for 1 hour between 30 and $70^{\circ} \mathrm{C}$ and the residual activity was measured at $25^{\circ} \mathrm{C}$. It is shown in Fig. 5 that we have engineered lipase to make it thermo stable. The introduction of a single disulfide in PVL lipase significantly stabilized PVL, increasing the halfinactivation temperature (IT1/2) from $37^{\circ} \mathrm{C}$ for the WT-PVL to $50^{\circ} \mathrm{C}$ for the PVL $\mathrm{C}^{\mathrm{C} 181-238}$ engineered one. Also, as seen in Fig. 6, when incubating at a constant $50^{\circ} \mathrm{C}$, the half-life increased from less than $12 \mathrm{~min}$ for wild-type to $120 \mathrm{~min}$ for the PVL ${ }^{\mathrm{C} 181-238}$. So PVL ${ }^{\mathrm{C} 181-238}$ showed good activity at higher temperatures compared to wild type. 


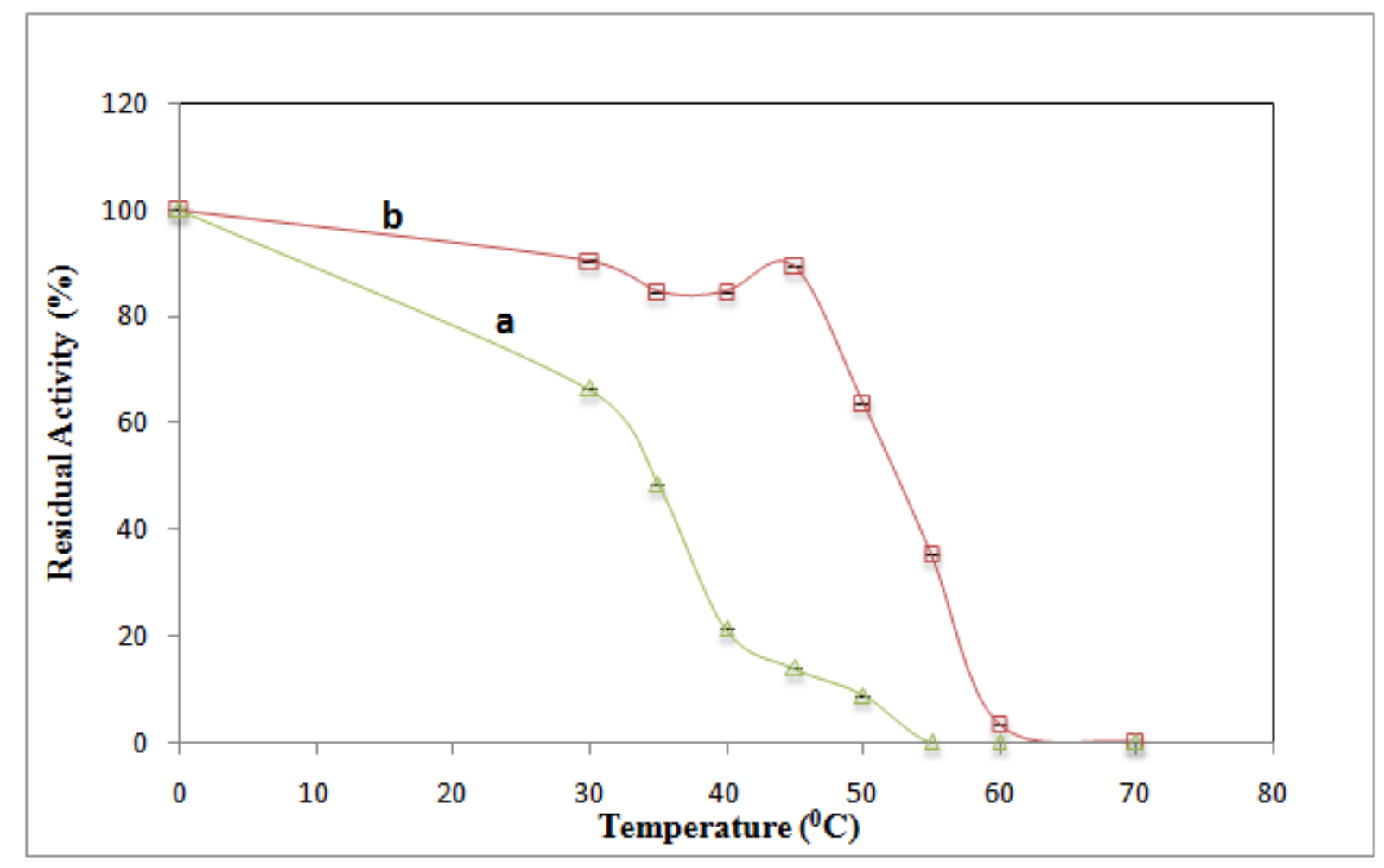

Figure 5: Temperature resistance after $1 \mathrm{~h}$ incubation for different temperatures:, (a) PVL $^{\mathrm{C} 181-238}$ and (b) WT- PVL

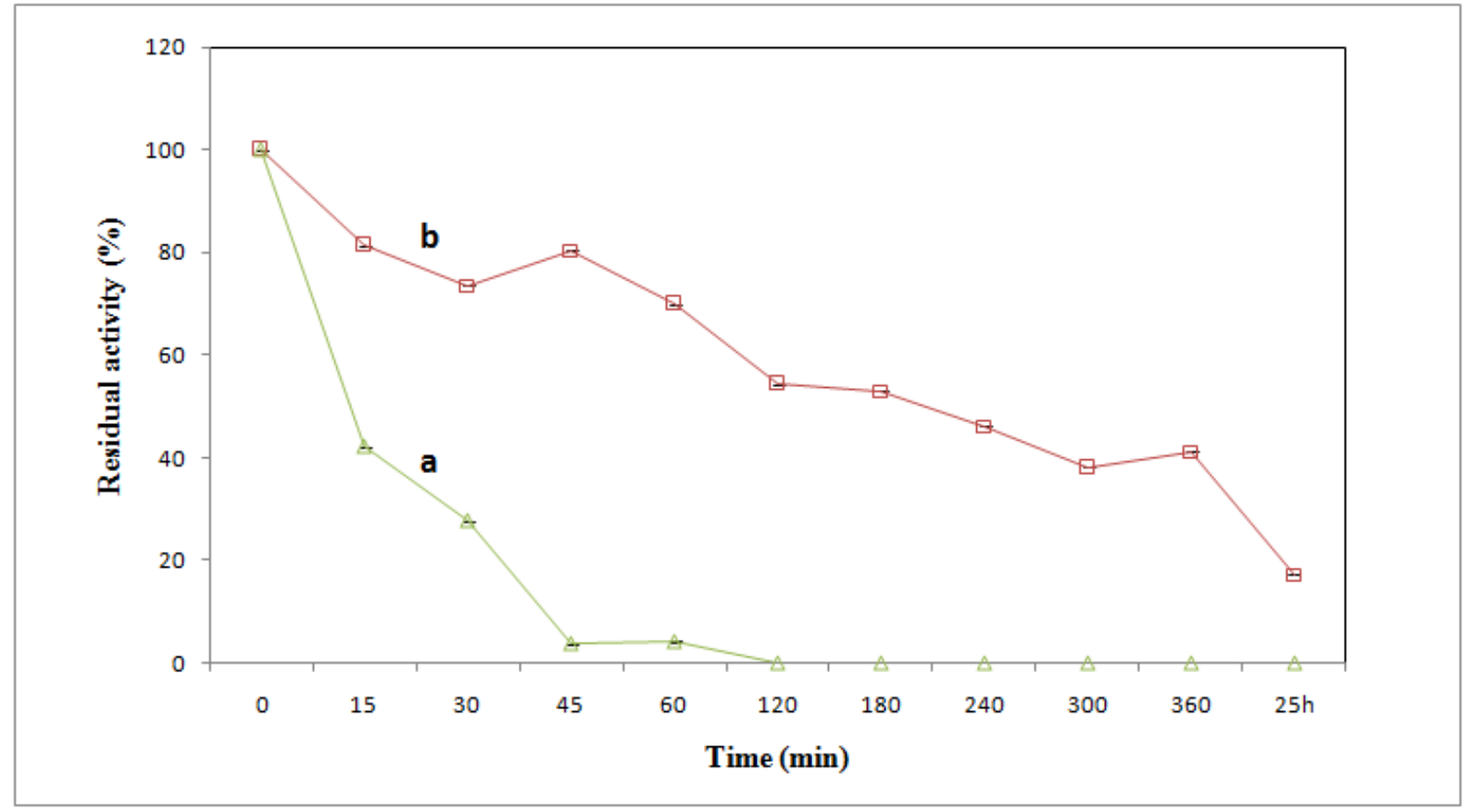

Figure 6: $50^{\circ} \mathrm{C}$ Temperature incubation for different time (h), (a)- PVL ${ }^{\mathrm{C} 181-238}$ and (b) WTPVL 


\subsection{Immobilization of lipases on PS beads}

The PS beads were prepared by wet phase inversion technique using a syringe. PS solutions were poured slowly with a syringe to lipase solution to form beads with lipase entrapped in pores. N,N-dimethyl formamide was preferred for the preparation of PS solution for its slow dissolution ability. The slow dissolution in $\mathrm{N}, \mathrm{N}$-dimethyl formamide resulted in homogeneous nature [34,35]. The basic methodology of wet phase inversion was the diffusion exchange between N,N-dimethyl formamide (solvent for PS) and water (nonsolvent for PS). Fig. 7 the scanning electron micrograph showed the cross sectional image of porous polysulfone globules having lipase immobilized. The asymmetric structure consists of polymer-rich phase and poor phase is formed as described because of the surface tension gradient between PS and NN dimethyl formamide in the globules. These beads had asymmetric nature due to the diffusional exchange of NN dimethyl formamide and water, similar to the flat sheet PS membranes [36,15]. The attractive feature of these globules was 'lipase immobilization' that occurs at the time of globule preparation. Lipase was entrapped in pores of globules. The amount of immobilized lipase in beads was estimated $750 \mathrm{ug} / \mathrm{g}$ by Lowry method.

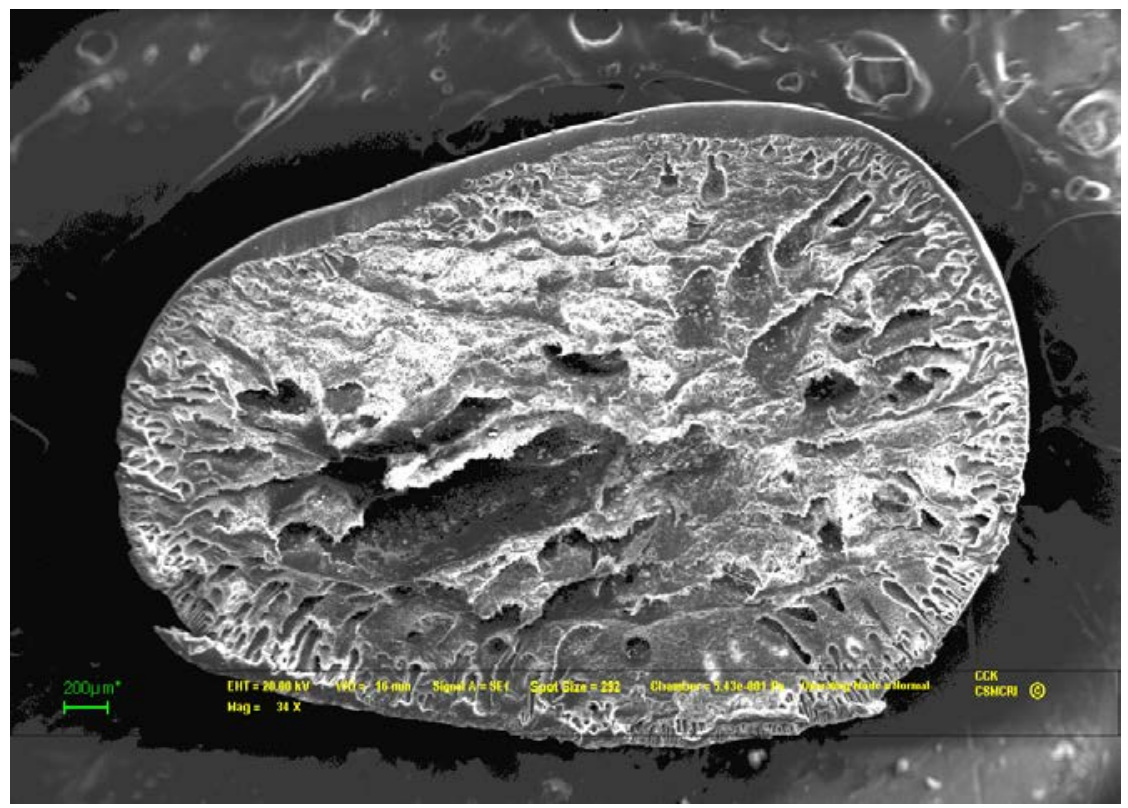

Figure 7: Asymmetric structure of PS globule having lipase immobilized (cross section) 


\subsection{Effect of ultrasound on trans-esterification reaction}

In order to study the effect of ultrasound on enzyme-catalysed biodiesel synthesis, transesterification reaction was carried out in the absence and presence of ultrasound. In the absence of ultrasound, the reaction was carried out with $0.1 \mathrm{~g}$ PVL loaded PS beads, neem oil and methanol to oil molar ratio of 5:1 at a shaking rate of $150 \mathrm{rpm}$. Even after 2 hours of the reaction, negligible yield ( $10 \%$ ) was obtained for WT-PVL and after about 24 hours, close to $75 \%$ and $43 \%$ conversions were observed for PVL ${ }^{\mathrm{C} 181-238}$ and WT-PVL, respectively (Figure 8). The slow reaction and low yield of the biodiesel are attributed to poor mixing of the alcohol and oil as they are not completely miscible with one another. Hence, poor mass transfer is a major issue for such enzyme catalysed transesterification reactions.

The reaction carried out in the presence of ultrasound (Fig. 8) using $20 \mathrm{kHz}$ ultrasonic horn with a probe diameter of $1 \mathrm{~cm}$ and ultrasonic power of $40 \mathrm{~W}$. For the synthesis reaction, $0.625 \mathrm{~mL}$ of $50 \%$ methanol (1:1 methanol: $0.1 \mathrm{M}$ phosphate $\mathrm{pH} 7.0$ ) was added to the $0.1 \mathrm{~g}$ beads having PVL ${ }^{\mathrm{C} 181-238}$ as well as WT-PVL followed by $1.5 \mathrm{~mL}$ neem oil. For PVL ${ }^{\mathrm{C} 181-238}$, it provided 65\% conversion in 15 minutes and almost complete $98 \%$ conversion was obtained in 30 minutes which is very higher than reported by Chen et al. that the biodiesel yield could be achieved about $70 \%$ after 40 min [37]. In another report, a two-step process was used and biodiesel with $96 \%$ yield was obtained after reaction for $1.5 \mathrm{~h}$ [38]. The ultrasonic-assisted transesterification of palm oil in the presence of alkaline earth metal oxide catalysts $(\mathrm{CaO}$, $\mathrm{SrO}$ and $\mathrm{BaO}$ ) was investigated and they required 60 min to achieve 95\% yield [39].

Enhanced yield in the presence of ultrasound is ascribed to the physical effects of ultrasound, which help the formation of fine emulsion between immiscible fluids resulting in an increase rate of transesterification reaction. WT-PVL showed esterification activity only 62\% conversion in 30 minutes in ultrasonication, which may be due to a rise in temperature and shear forces that may have caused the inactivation of the enzyme. Commercial B. cepacia lipase was also used for comparison and we found that biodiesel synthesis was less without sonication. Without the use of an enzyme, even one hour of sonication didn't provide any conversion of neem oil to biodiesel, which suggests that just physical mixing of the liquids alone is not sufficient for transesterification reaction. 


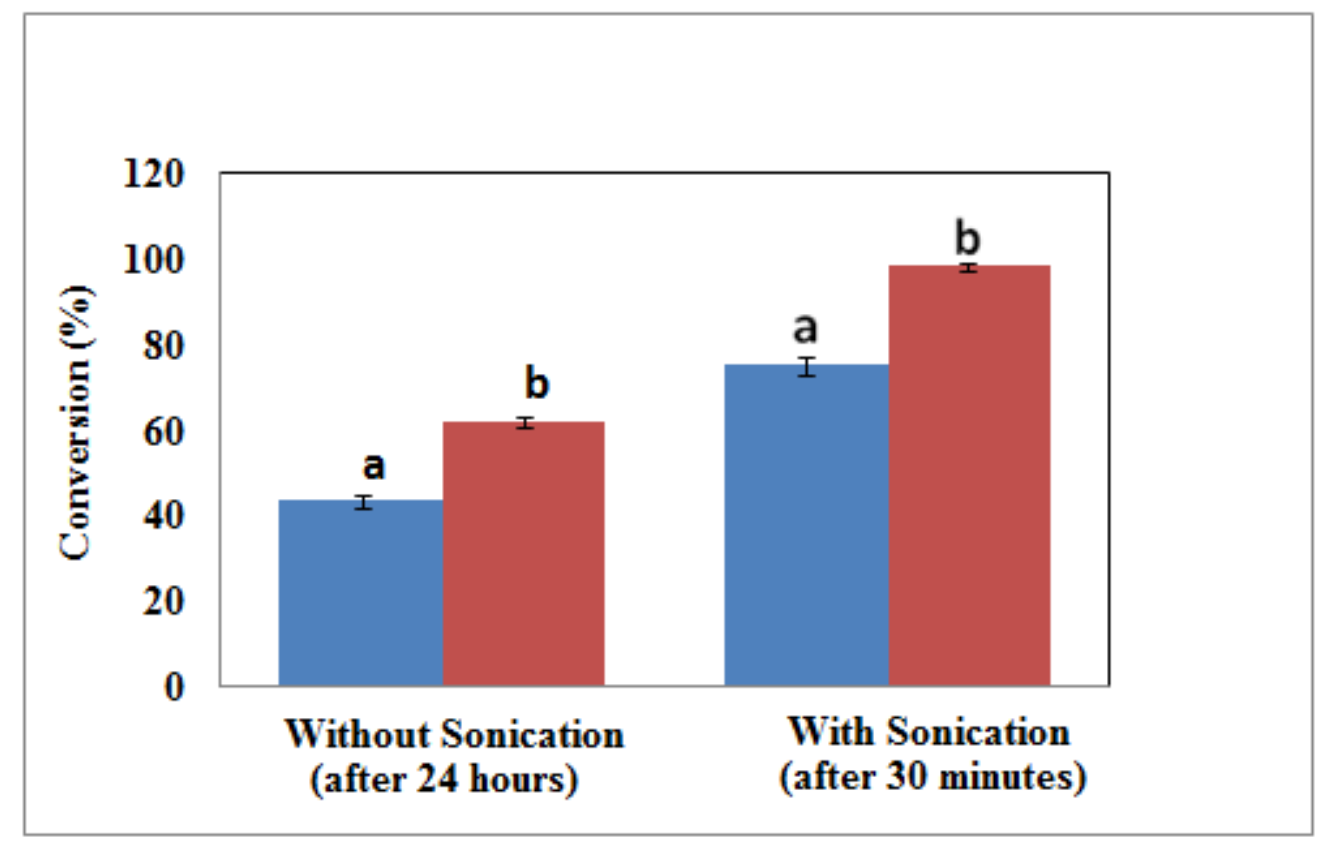

Figure 8: Percentage of biodiesel (FAME) synthesized as a function of sonication and without sonication, (a) WT-PVL, (b) PVL $181-238$

\subsection{Reuse of immobilized PVL}

As the target of this study is to develop a stable lipase that is less prone to temperature induced inactivation during biodiesel synthesis, experiments were done to check the ability of $\mathrm{PVL}^{\mathrm{C} 181-238}$ to retain transesterification activity for many cycles over a long period of time. For biodiesel synthesis, $150 \mu \mathrm{g}$ lipase covalently immobilized on $200 \mathrm{mg}$ beads were added to a mixture of $0.625 \mathrm{ml}$ of $50 \%$ methanol and $1.5 \mathrm{ml}$ of neem oil. This mixture provides a $\sim 5: 1$ molar ratio of methanol to triacylglycerol oil. For each cycle the progress of the reaction was monitored for 30 minutes. For the every next cycle, the beads were washed with water wash to remove glycerol and residual methanol followed by hexane wash to remove residual oil and fatty acid methyl esters (FAMEs). The results of many cycles of biodiesel synthesis are displayed in Fig. 9. During the first cycle the rate of biodiesel synthesis showed 98\%, 76\% and 62\% conversiosn to FAME for PVL ${ }^{\mathrm{C} 181-238}$, B. cepacia lipase and WT-PVL, respectively. After that the rate of synthesis decreased slowly for next cycles for PVL ${ }^{\mathrm{C} 181-238}$ but it still converting $67 \%$ of neem oil to biodiesel. This very little loss in activity was seen after fifth cycle, as the enzymes have a finite lifetime and their activity decreases slowly during the repeated use by the loss of structural conformation. On the other hand WT-PVL and B. cepacia lipase lost almost all of its activity to convert neem oil in biodiesel (FAME) in 
second cycle may be due to rise in temperature and shear forces that may have caused the inactivation of the enzyme.

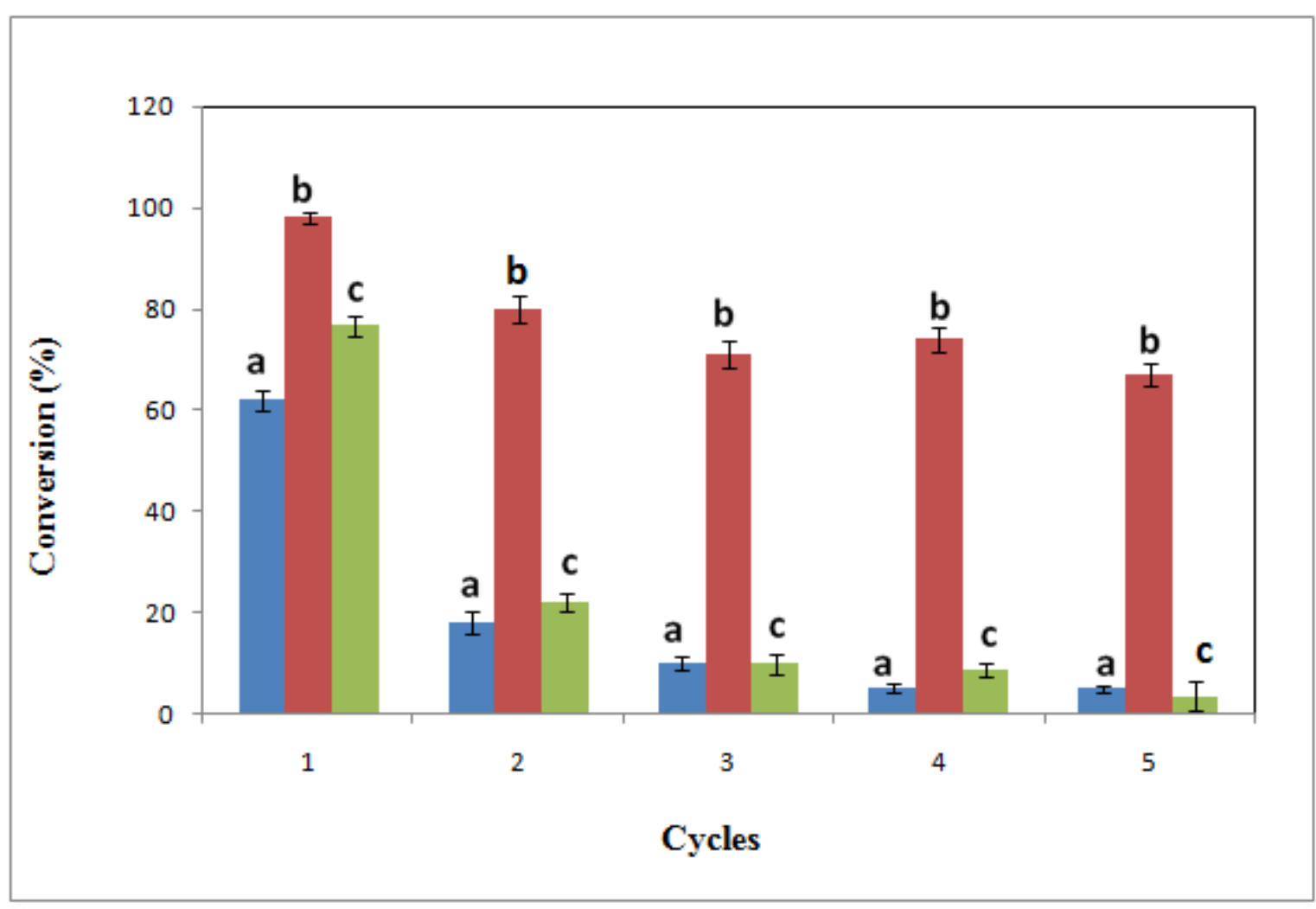

Figure 9: Reuse of (a) WT-PVL, (b) PVL ${ }^{\mathrm{C} 181-238}$ \& (c) B. cepacia lipase, immobilized on PS beads for 5 cycles.

\section{Conclusion}

Lipase-catalyzed biodiesel production from non edible sources has several advantages over the conventional chemical-catalyzed process, including lower environmental concerns and energy consumption. The low stability and high cost of lipase, however, have been the main hurdles for the industrialization of lipase-catalyzed biodiesel production. The present work has demonstrated the efficient enzymatic transesterification of neem oil with methanol under the influence of ultrasound using thermostable lipase from Proteus vulgaris as a catalyst. In order to improve the thermostability of the enzyme, we have introduced disulfide bond in the lipase gene. In order to improve the rate of transesterification, we have used sonication. The results clearly shed light on the importance of ultrasound in biodiesel synthesis. Although the 
reported ultrasonic effects vary widely, the major benefit observed from ultrasonication is the much shorter reaction time. Sonication decreases the reaction time to $\sim 30$ minutes as compared to 22-24 hours without ultrasonic treatment. Ultrasonication is a promising and efficient technique for biofuel synthesis but the temperature increase due to sonication is a hurdle for temperature labile enzymes. In this context, protein engineering by introduction of disulfide bond and enzyme immobilization are essential to address the challenges noted above.

Acknowledgement: Authors want to acknowledge YS scheme (DST), Endeavour Australian Research Fellowships for funding the research. 


\section{References:}

1. Fukuda H, Kondo A, Noda H. Biodiesel fuel production by transesterification of oils. J Biosci \& Bioengg 2001;92;405-16.

2. Vicente G, Martínez M, Aracil J. Integrated biodiesel production: a comparison of different homogeneous catalysts systems. Biores Tech 2004;92:297-305.

3. Shimada Y, Watanabe Y,Sugihara A, TominagaY. Enzymatic alcoholysis for biodiesel fuel production and application of the reaction to oil processing. J Mol Cat B: Enz 2002;17:133-42.

4. Ayhan D. Biodiesel fuels from vegetable oils via catalytic and non-catalytic supercritical alcohol transesterifications and other methods: a survey. Energy Converse Manage 2003;44:2093-109.

5. Gog A, Roman M, Toşa M, Paizs C, Irimie FD. Biodiesel production using enzymatic transesterification - current state and perspectives. Renew Energy 2012;39:10-6.

6. Nie K, Xie F, Wang F, Tan T. Lipase catalyzed methanolysis to produce biodiesel: Optimization of the biodiesel production. J Mol Cat B: Enz 2006;43:142-47.

7. Fjerbaek L, Christensen KV, Norddahl B. A review of the current state of biodiesel production using enzymatic transesterification. Biotech \& Bioengg 2009;102:1298315.

8. Arpigny JL, Jaeger KE. Bacterial lipolytic enzymes: classification and properties. Biochem J 1999;343:177-83.

9. Connor MR, Liao JC. Microbial production of advanced transportation fuels in nonnatural hosts. Curr Opinion Biotechnol 2009;6:307-15.

10. Le QAT, Joo JC, Yoo YJ, Kim YH. Development of thermostable Candida antarctica lipase B through novel in silico design of disulfide bridge. Biotechnol Bioeng 2012; 109:867-76.

11. Gupta S, Bhattacharya A, Murthy CN. Tune to immobilize lipases on Polymer Membranes: Techniques, Factors and Prospects. Biocat \& Agri Biotech 2013;2:17190.

12. Gupta S, Ingole P, Singh K, Bhattacharya A. Comparative study of Hydrolysis of different Oils by lipase immobilized membranes. J App Pol Sc 2012;124:17-26.

13. Gupta S. Comparative study on hydrolysis of oils by lipase immobilized biocatalytic PS membranes using biphasic enzyme membrane reactor. J Envir Chem Engg2016;4:1797-809. 
14. Gupta S, Yogesh, Singh K, Bhattacharya A. Lipase immobilized on Poly (vinyl alcohol) modified Polysulfone membrane: Application in hydrolytic activities for olive oil. Polym Bulletin 2010;64:141-58.

15. Gupta S, Yogesh, Javiya S, Bhambi M, Pundir CS, Singh K, Bhattacharya A. Comparative study of performances of Lipase immobilized asymmetric polysulfone and polyether sulfone membranes in olive oil hydrolysis. Int $\mathrm{J}$ Bio Macromol 2008;42:145-51.

16. Yanli F, Guiying W, Feng S, Kai L, Li X, Xiaotao H, Yunjun Y. Lipase orientedimmobilized on dendrimer-coated magnetic multi-walled carbon nanotubes toward catalyzing biodiesel production from waste vegetable oil. Fuel 2016;178:172-8.

17. Veymar GTP, Jose JVO, Mauricio JP, Malcolm Y, Beatriz TS, Arnulfo RQ, Roberto FL. Evaluation of different lipase biocatalysts in the production of biodiesel from used cooking oil: Critical role of the immobilization support. Fuel 2017;200:1-10.

18. Puri M, Barrow CJ, Verma ML. Enzyme immobilization on nanomaterials for biofuel production. Trends in Biotech 2013;31:215-16.

19. Bhangu SK, Gupta S, Muthupandian A. Ultrasonic enhancement of lipasecatalysedtransesterification for biodiesel synthesis. Ultrason Sonochem 2017;34:3059.

20. Singh A K, Fernando SD, Hernandez R. Base-Catalyzed Fast Transesterification of Soybean Oil Using Ultrasonication. Energy \& Fuels 2007;21: 1161-64.

21. Veljković VB, Avramović JM, Stamenković OS. Biodiesel production by ultrasound assisted transesterification: state of the art and perspectives. Renew Sustain Energy Rev 2012;16:1193-209.

22. Sivaramakrishnan R, Incharoensakdi A. Direct transesterification of Botryococcus sp. catalysed by immobilized lipase: Ultrasound treatment can reduce reaction time with high yield of methyl ester. Fuel 2017; 191: 363-70.

23. Liu Y, Jin Q, Shan L, Liu Y, Shen W, Wang X. The effect of ultrasound on lipasecatalyzed hydrolysis of soy oil in solvent-free system. Ultrason sonochem 2008;15:402-7.

24. Mahamuni NN, Adewuyi YG. Optimization of the synthesis of biodiesel via ultrasound-enhanced base-catalyzed transesterification of soybean oil using a multifrequency ultrasonic reactor. Energy Fuels 2009;23:2757-66.

25. Thanh LT, Okitsu K, Sadanaga Y, Takenaka N, Maeda Y, Bandow H. A two-step continuous ultrasound assisted production of biodiesel fuel from waste cooking oils: 
A practical and economical approach to produce high quality biodiesel fuel. Biores Tech 2010;101: 5394-401.

26. Batistella L, Lerin LA, Brugnerotto P, Danielli AJ, Trentin CM, Popiolski A, Treichel H, Oliveira JV, de Oliveira D. Ultrasound-assisted lipase-catalyzed transesterification of soybean oil in organic solvent system. Ultrason sonochem 2012;19:452-58.

27. Cintas P, Luche JL. Green chemistry The sonochemical approach. Green Chem 1999;1:115-25.

28. Yang HM, Yao B,Meng K,Wang YR, Bai YG,Wu NF. Introduction of a disulfide bridge enhances the thermostability of a Streptomyces olivaceoviridis xylanase mutant. J Ind Microbiol Biotechnol 2007;34:213-8.

29. Lowry OH, Rosebrough NJ, Farr AL, Randall RJ. Protein measurement with the Folinphenol reagent. JBiolChem1951;193 (1): 265-75.

30. Gupta S,Singh K, Bhattacharya A. Lipase immobilization on Polysulfone globules and their performances in olive oil hydrolysis. Int J Biol Macromol 2010;46:445-50.

31. Han Z, Han S, Zheng S, Lin Y. Enhancing thermostability of a Rhizomucormiehei lipase by engineering a disulfide bond and displaying on the yeast cell surface. Appl Microbiol Biotechnol 2009;85:117-26.

32. Nardini M, Lang DA, Liebeton K. Crystal structure of pseudomonas aeruginosa lipase in the open conformation THE prototype for family I.1 of bacterial lipases. J Biol Chem 2000;275:31219-25.

33. Kim KK, Song HK, Shin DH, Hwang KY, Suh SW. The crystal structure of a triacylglycerol lipase from Pseudomonas cepacia reveals a highly open conformation in the absence of a bound inhibitor. Structure 1997;5:173-85.

34. Gupta S, Yogesh, Singh K, Bhattacharya A. Studies on Permeation of Bovine serum Albumin (BSA) through photo modified functionalized asymmetric membrane. J Macromol Sci Part A: Pure Appl Chem 2009;46:90-6.

35. Gohil JM, Bhattacharya A, Ray P. Effect of Polymeric surface-active agents in the phase inversion step of asymmetric membrane formation. J Surf Sci Tech 2004;20:17.

36. Kesting R. Synthetic polymeric membranes: A Structural Perspective.2nd edition. New York: Wiley-Interscience;1985. 
37. Chena G,Shan R, Shi, J,Yana B. Ultrasonic-assisted production of biodiesel from transesterification of palm oil over ostrich eggshell-derived $\mathrm{CaO}$ catalysts.Biores Tech 2014;171:428-32.

38. Deng X, Fang Z, Liu Y, Ultrasonic transesterification of Jatrophacurcas L. oil to biodiesel by a two-step process. Energy Convers Manage 2010;51:2802-7.

39. Mootabadi H, SalamatiniaB, Bhatia S, Abdullah AZ.Ultrasonic-assisted biodiesel production process from palm oil using alkaline earth metal oxides as the heterogeneous catalysts. Fuel 2010;89:1818-25. 


\section{University Library}

\section{- M M N E R VA A gateway to Melbourne's research publications}

Minerva Access is the Institutional Repository of The University of Melbourne

Author/s:

Gupta, S;Scott, D;Prabha, R;Ashokkumar, M

Title:

Biodiesel synthesis assisted by ultrasonication using engineered thermo-stable Proteus vulgaris lipase

Date:

2017-11-15

Citation:

Gupta, S., Scott, D., Prabha, R. \& Ashokkumar, M. (2017). Biodiesel synthesis assisted by ultrasonication using engineered thermo-stable Proteus vulgaris lipase. FUEL, 208, pp.430-438. https://doi.org/10.1016/j.fuel.2017.07.041.

Persistent Link:

http://hdl.handle.net/11343/241895 